\title{
Immunoregulatory effect of mouse fetal neural cells on the graft-versus-host disease
}

\author{
Goltsev A. M., Babenko N. M., Gaevska Yu. O., Dubrava T. G., Lutsenko O. D., Bondarovych M. O. \\ Institute for Problems of Cryobiology and Cryomedicine of the National Academy of Sciences of Ukraine, Kharkiv, Ukraine \\ e-mail: cryopato@gmail.com
}

\section{ABSTRACT}

The problem of the treatment of acute and chronic graft-versus-host disease (GVHD), when histoincompatible bone marrow (BM) is used, remains unsolved. An important role in controlling the development of GVHD is played by Treg immunity.

The PURPOSE of the study is to evaluate the immunoregulatory effect of native and cryopreserved murine fetal neural cells (FNCS) relative to Treg immunity of mice with GVHD.

MATERIALS AND METHODS. Acute GVHD was induced by the injection of histoincompatible BM to lethally irradiated mice. On the $14^{\text {th }}$ day after GVHD induction and transplantation of native or cryopreserved FNCs in animals of all experimental groups, the spleen index, the number of T-regulatory (FOXP3 $3^{+}$) cells and the number of foxp3 gene transcripts in the $\mathrm{CD}^{+}$splenocytes were determined.

RESULTS. The recipients of the histoincompatible BM had a decrease in the number of Treg cells and the level of foxp3 gene expression in the splenocyte population relative to the syngeneic control. Injection of native or cryopreserved FNCs to animals with GVHD caused an increase in the number of Treg cells. Cryopreserved FNCs are more than native ones enhancing both the relative number of Treg cells and the level of foxp3 gene expression in the splenocytes, which was characterized by a higher recipients' survival up to the $16^{\text {th }}$ day of observation.

CONCLUSION. The transplantation of fetal neural cells to recipients with GVHD stimulates the Treg immunity, which is a key to the development of immune conflict. This confirms the possibility of using fetal neural cells as a therapeutic immuno-regulatory agent.

KEY WORDS: fetal neural cells; graft-versus-host disease; Treg cells; foxp3 gene

A serious disadvantage of transplantation of histoincompatible bone marrow (BM) in clinic is the development of acute or chronic form of the «graft-versus-host» disease (GVHD) in a recipient [1, 2]. At present, a variety of approaches to recipient support or bone marrow (BM) treatment to remove T-lymphocytes that are responsible for the GVHD are used to prevent or minimize the development of this pathology. These include BM treatment with monoclonal antibodies (mAb) to T-lymphocytes with complement, conjugation of anti-T-cell mAb with immunotoxins, elutriation, T-cell soybean lectin agglutination, immunoadsorption, etc. [3]. The gentlest procedure is immunomagnetic separation, in which BM cells remain viable, while removing most T-lymphocytes [4]. However, the elimination of T-lymphocytes from BM causes impairment of the cell transplant engraftment, the loss of the ability to implement the graftversus-leukemia effect, the development of infectious complications and, as a consequence, an increase in patients' mortality [5].

One of the alternative approaches to changing the cell composition of the BM and minimizing the severity of GVHD is the use of certain regimes of its cryopreservation [6]. In this case, the reduction of the graft- versus-host reaction at the transplantation of the histoincompatible bone marrow occurs due to selective elimination of cytokine-producing regulatory cells of the mononuclear phagocyte system, which are part of BM adhesive cell fraction. Removal of adhesive BM cells was accompanied by a decrease in the activity of Thy-1.2+ T-lymphocytes, which are related to the development of GVHD [7]. Regulation of effector donor T-cells may be performed not only by the receptor's antigen presenting cells, but also by the stromal cells of the myelotransplantant, which may include mesenchymal stromal cells (MSCs). These cells exhibit pronounced immunosuppressive properties when administered to recipients with GVHD $[8,9]$. MSCs prevent GVHD by direct or indirect induction of Treg from naive $\mathrm{CD}^{+}$-cells in vivo. Alongside, further search for the ways to reduce the immunoreactivity of the histoincompatible BM continues.

GVHD is a systemic pathology when coordination of the immune system interaction with other systems of an organism is violated in the recipient's body $[2,10,11]$. The greatest role in the transplant rejection belongs to MHC antigens, which differences induce T-cell immune response. In acute experimental GVHD, the main target of donor T-lymphocytes 
is cells expressing MHC-II molecules (Langerhans cells in the skin, dendritic and epithelial cells in the thymus, etc.) [11]. The results that indicate the development of a concomitant immunodeficiency in patients with histoincompatible BM transplantation, which manifests as complications from both the peripheral and central nervous systems, are fundamentally important $[10,12]$

Fetal neural cells (FNCs) belong to such cell products that are able to replace lost neurons at trauma or neurodegenerative disorders $[13,14]$. FNCs have pronounced immunotropic potential and immunoregulatory activity $[15,16]$. One of the vectors of FNCs immunosuppressive activity, in particular dendritic cells of the brain, micro- and macroglial cells, is realized by secretion of the indolamine-2,3-dioxygenase (IDO) enzyme. This key enzyme of the kynurenine pathway results in the metabolism of excess tryptophan to active metabolites such as kynurenine, kynurenic acid, 3-hydroxykynurenine, 3-hydroxyanthranilic, picolinic and quinolinic acids [17]. The lack of tryptophan suppresses the proliferation of effector T-cells and leads to the stop of their cell cycle by acting in several ways: by activating GCN2-kinase or inhibiting mTOR $[18,19]$. In addition, IDO catabolites, in particular kynurenine, are strong aryl-hydrocarbon receptor activators (AhR), by which induction of apoptosis of immune cells occurs [20].

Another aspect of the immunoregulatory effects of IDO is to stimulate the differentiation of naive $\mathrm{CD} 4^{+}$cells in Treg cells. In particular, kynurenine and its derivatives in combination with TGF- $ß$ promote the activation of foxp3 gene acting through AhR, which causes the formation of the Treg subpopulation [21]. Kynurenine pathway of tryptophan degradation is the most common in macrophages and microglial cells [22] and partly in astrocytes [23].

Interferon- $\gamma$ (IFN- $\gamma$ ) is the most powerful inductor of IDO [24]. In the presence of IFN- $\gamma$, murine fetal brain astrocytes, microglia and neurons in vitro are capable of expressing ID0 in an amount sufficient to detect [25]. Besides IFN- $\gamma$, such a significant stress-inducing factor as cryopreservation has the ability to activate the expression of the ido gene in the FNCs of 11-12 dpc mice. In the cryopreserved FNCs, the expression of the ido gene increased, and subsequent in vitro cultivation in the presence of IFN- $\gamma$ further enhanced the activation of ido producing cells [16]. This allows us to consider FNCs as a therapeutic agent with immunoregulatory properties when administered with BM for GVHD treatment.

Many studies show the aggravation of GVHD clinical symptoms manifestations in the case of decrease in Treg number [26, 27], whose suppressive effects is due to the transcription factor FOXP3 controlled by foxp3 gene. That is, the decrease in both the level of foxp3 gene expression in Treg and their concentration in recipients with GVHD are molecular biomarkers of this pathology.

The PURPOSE of the study was to determine the immunoregulatory effect of native and cryopreserved murine fetal neural cells on the Treg immunity of mice with GVHD.

\section{MATERIALS AND METHODS}

Experiments were performed on 20-week-old female $\mathrm{CBA} / \mathrm{H}$ mice and first-generation hybrid mice $(\mathrm{CBA} / \mathrm{H} \times \mathrm{C} 57 \mathrm{BI} / 6) \mathrm{F}_{1}$ weighing $24-26 \mathrm{~g}$. The research was conducted in accordance with the «European Convention for the Protection of Vertebrate Animals Used for Experimental and Other Scientific Purposes» (European Convention, Strasburg, 1986) and approved by the 1st National Congress of Bioethics (Kyiv, 2004). The animals were euthanised by cervical dislocation under ether anaesthesia on the $14^{\text {th }}$ day after GVHD induction.

Obtaining of cell suspensions. Inguinal lymph nodes and bone marrow (BM) were obtained from $\mathrm{CBA} / \mathrm{H}$ mice. The lymph nodes were homogenated in a Potter homogenizer in the medium 199 (PanEco, Russia) supplemented with $10 \%$ fetal bovine serum (HyClone, USA) and $2 \%$ sodium citrate (Sigma-Aldrich, USA) (working medium 1). The bone marrow was flushed out of the femoral bones by the working medium 1 . The resulting suspensions were passed through nylon filters (Falkon, USA) with a pore diameter of $100 \mu \mathrm{m}$.
FNCs suspension was obtained from the brain of the CBA/H fetuses on the $12^{\text {th }}$ day of gestation. The term of pregnancy of animals was calculated from the day of vaginal copulation plug presence. The excised mice fetuses were washed three times with Hanks' solution (PanEco, Russia). The fragments of the brain were disintegrated in $3 \mathrm{~mL} D M E M / F 12 \mathrm{me}-$ dium (Serva, Germany) supplemented with $20 \%$ fetal bovine serum ( $\mathrm{Hy}$ Clone, USA) by passing through the needles with decreasing diameter. The time from the moment of obtaining the fetuses to the preparation of the cell suspension did not exceed one hour.

Cryopreservation of FNCs was carried out in the working medium 2 containing DMEM/F12 (Serva, Germany), 0.6 mg\% glucose (Galychpharm, Ukraine), $10 \%$ fetal bovine serum (HyClone, USA), 0,2 units/mL insulin (Berlin-Chemie, Germany) with the addition of $10 \%$ dimethyl sulfoxide (Arterium, Ukraine) as cryoprotectant. The freezing mode was performed by cooling samples at a rate of $1{ }^{\circ} \mathrm{C} / \mathrm{min}$ to $-80^{\circ} \mathrm{C}$ followed by transfer in liquid nitrogen [16]. Thawing of FNCs was carried out in a water bath at $37^{\circ} \mathrm{C}$ for $50-60$ seconds until the disappearance of the solid phase. Washing of FNCs suspension to remove cryoprotectant was carried out by adding an equal volume of the working medium 2 and subsequent centrifugation at $300 \mathrm{~g}$. A suspension of FNCs that did not undergo a freeze-thaw procedure is referred as native.

Preculture of native and cryopreserved FNCs was performed in DMEM/F12 medium (Serva, Germany) supplemented with $15 \%$ fetal bovine serum in Petri dishes, coated with BioCoat Laminin/Fibronectin (BD Pharmingen, USA) at $37{ }^{\circ} \mathrm{C}$ for 48 hours. In order to stimulate the expression of $i d o$ gene, IFN- $\gamma$ (Sigma-Aldrich, USA) at a concentration of 100 units/mL was added in FNCs culture in 24 hours. After 24 hours, native and cryopreserved FNCs were transplanted intravenously to irradiated recipients as an immunomodulatory agent.

\section{THE INDUCTION OF ACUTE GVHD}

Acute GVHD was induced in mice $(\mathrm{CBA} / \mathrm{HxC57BI}) \mathrm{F}_{1}$ that were irradiated by RUM-17 device (Mosrentgen, Russia) at a dose of 8.50 Gy [27]. Conditions of exposure: dose rate $-0.38 \mathrm{~Gy} / \mathrm{min}$; voltage $-220 \mathrm{kV}$; current strength $-10 \mathrm{~mA}$; filters $-0.5 \mathrm{~mm} \mathrm{Cu}+1 \mathrm{~mm} \mathrm{Al}$; focal-dorsal distance $-50 \mathrm{~cm}$. One hour after the exposure, the animals were intravenously injected with $5 \cdot 10^{6} \mathrm{cells} /$ mouse of syngeneic or histoincompatible BM of $\mathrm{CBA} / \mathrm{H}$ mice along with the cells of the inguinal lymph nodes of the same strain in a ratio $3: 1$, respectively. Since, in the human BM, the lymphocyte percentage is approximately $30 \%$, and it is much less in mice, we added BM to the syngeneic lymph node cells in the corresponding amount [28].

Experimental animals were divided into the following groups $(n=10)$ :

1 - intact mice $(\mathrm{CBA} / \mathrm{H} \times \mathrm{C} 57 \mathrm{BI}) \mathrm{F}_{1}$;

2 - irradiated mice $(\mathrm{CBA} / \mathrm{H} \times \mathrm{C} 57 \mathrm{BI}) \mathrm{F}_{1}$, which were injected with saline solution;

3 - irradiated mice $(\mathrm{CBA} / \mathrm{H} \times \mathrm{C} 57 \mathrm{BI}) \mathrm{F}_{1}$, which were injected with syngeneic $\left(\mathrm{CBA} / \mathrm{HxC57BI)} \mathrm{F}_{1}\right.$ bone marrow at a dose of $3.5 \cdot 10^{6} /$ mouse with lymph node cells from $(\mathrm{CBA} / \mathrm{HxC57BI}) \mathrm{F}_{1}$ mice, $1.5 \cdot 10^{6} \mathrm{cells} / \mathrm{mouse}$;

4 - irradiated mice $(\mathrm{CBA} / \mathrm{H} \times \mathrm{C} 57 \mathrm{BI}) \mathrm{F}_{1}$, which were injected with histoincompatible $\mathrm{CBA} / \mathrm{H}$ bone marrow at a dose of $3.5 \cdot 10^{6}$ cells/mouse with lymph node cells from $\mathrm{CBA} / \mathrm{H}$ mice, $1.5 \cdot 10^{6}$ cells/mouse;

5 - irradiated mice $(\mathrm{CBA} / \mathrm{H} \times \mathrm{C} 57 \mathrm{BI}) \mathrm{F}_{1}$, which were injected with histoincompatible $\mathrm{CBA} / \mathrm{H}$ bone marrow at a dose of $3.5 \cdot 10^{6}$ cells/mouse with lymph node cells from $\mathrm{CBA} / \mathrm{H}$ mice, $1.5 \cdot 10^{6} \mathrm{cells} /$ mouse and native FNCs from $\mathrm{CBA} / \mathrm{H}$ mice, $5 \cdot 10^{5}$ cells/mouse;

6 - irradiated mice $(\mathrm{CBA} / \mathrm{H} \times \mathrm{C} 57 \mathrm{BI}) \mathrm{F}_{1}$, which were injected with histoincompatible $\mathrm{CBA} / \mathrm{H}$ bone marrow at a dose of $3.5 \cdot 10^{6}$ cells/mouse and lymphocyte cells from $\mathrm{CBA} / \mathrm{H}$ mice, $1.5 \cdot 10^{6}$ cells/mouse with cryopreserved FNCs from CBA/H mice, $5 \bullet 10^{5}$ cell/mouse.

The volume of saline and cell suspension, which were injected intravenously, was $0.2 \mathrm{~mL} / \mathrm{mouse}$.

\section{ESTIMATION OF THE INTENSITY OF GVHD}

The number of recipient mice, which survived after GVHD induction and treatment, was estimated up to the $16^{\text {th }}$ day. On the $14^{\text {th }}$ day after 
GVHD induction in animals of all experimental groups, the spleen index, Treg number and the number of foxp3 gene transcripts in isolated CD4 ${ }^{+}$ splenocytes were determined.

The spleen index was calculated as the ratio of organ mass to body weight multiplied by 100 . The spleen index of intact animals was taken as 1 , when in experimental groups it was more than 1.3 - this indicated the development of GVHD [27, 28].

To obtain splenocytes suspension, the mice spleens of all experimental groups were homogenized in the working medium 1. Then they were treated with a lysing buffer BD Pharmlyse ${ }^{\text {tm }}$ (BD Pharmingen, USA) according to the manufacturer's instructions to remove red blood cells. After that, the spleen cells were washed twice with phosphate buffer (Biowest, France) by centrifugation at $300 \mathrm{xg}$.

The relative number of Treg (Fox3 $\left.3^{+}\right)$cells in the spleen of animals of all experimental groups was determined on a flow cytometer FACS Calibur (Becton Dickinson, USA) using PE-conjugated anti-mouse monoclonal antibodies FOXP3 (BD Pharmingen, USA) according to manufacturer's protocol. Isotype-antibodies (BD Pharmingen, USA) were used as a negative control. To minimize errors, 10,000 events per samples were analysed. The FACS data were analysed using WimMDi 2.8 software (Joseph Trotter, Scripps Institute, La Jolla, USA).

Isolation of $\mathrm{CD}^{+}$fraction of spleen cells was performed by immunomagnetic sorting using anti-mouse CD4 Magnetic Particles-DM (BD $I M^{\prime} g^{T M}$, USA) on a magnetic sorter BD IMagnet (BD IMag ${ }^{T M}$, USA) according to the manufacturer's protocol.

\section{DETERMINATION OF THE NUMBER OF FOXP3 GENE}

\section{TRANSCRIPTS IN CD4+ FRACTION OF SPLEEN CELLS}

Isolation of RNA. The total RNA was isolated from $1 \cdot 10^{5}$ cells using Diatom RNA Prep 100 kit (Sintol, Russia) according to the manufacturer's instructions. To purify RNA samples from DNA contamination, the treatment with DNase (Synthol, Russia) was used. Samples were incubated with DNase (activity $2 \mathrm{U} / \mu \mathrm{l}$ ) at $37^{\circ} \mathrm{C}$ for $30 \mathrm{~min}$. Inactivation of DNase was carried out by heat the reaction mixture at $75^{\circ} \mathrm{C}$ for $10 \mathrm{~min}$.

Reverse transcription reaction. To synthesize the first DNA chain on the RNA matrix, a kit «Reverta $L$ » containing a mix of random-oligonucleotides and reverse transcriptase (CRIE, Russia) was used, according to the manufacturer's instructions (Sintol, Russia). Samples were incubated at $37^{\circ} \mathrm{C}$ for $30 \mathrm{~min}$. After completion of the reaction, the tubes were heated to $92^{\circ} \mathrm{C}$ to inactivate the revertase and incubated for 3-5 minutes.

Polymerase chain reaction. In the multiplex PCR, two pairs of primers were used (Table 1): foxp3 gene (NCBI Reference Sequence: NM_054039.2) and housekeeping $\beta$-actin gene (NCBI Reference Sequence: NM_007393.3), which were constructed using the database GenBank of the National Centre of Biotechnological Information (NCBI BLAST, USA) and synthesized at Medbioservice company (Ukraine).

The cDNA amplification was performed by PCR using a GenePakTM PCR Core reagent kit (Laboratory Isogene, Russia) containing Taq DNA polymerase inhibitor $(1 \mathrm{u})$, deoxynucleosidetriphosphate $(200 \mu \mathrm{M})$ and magnesium chloride $(2.5 \mathrm{mM})$ for "hot start" and an optimized buffer system for standard PCR. Using a mix of both primers, we performed a common «step-by-step» PCR [29], in which the synthesis of fragments specific to each target occurred. The number of cycles for each gene was selected in previous experiments by adding primers at different cycles in PCR, which avoids competition between the PCR of each gene, the loss of exponential amplification, and the decrease in the level of synthesized products. As a result, 40 cycles were performed for foxp 3 gene, 20 cycles for $\beta$-actin. The amplification was carried out in a thermostat Tertsik (NVF DNA-technology, Russia). The denaturation was carried out at $94{ }^{\circ} \mathrm{C}$ for 30 seconds; the hybridization of the matrix with the primer at $60^{\circ} \mathrm{C}$ was 30 seconds, the elongation - at $72{ }^{\circ} \mathrm{C}$ for 60 seconds. Negative control was a reaction mixture without cDNA.

Detection of amplification products was performed by capillary electrophoresis in a 2100 Bioanalyzer system (Agilent, USA). Preparation of chips was carried out in accordance with the instructions for the kit
«DNA 1000» (Fermentas, Lithuania). PCR products were transferred into the chips and automatically registered in the microchannels. The control was the marker of the fragments' length, which was transferred into a separate well.

The number of gene transcripts $(\mathrm{nmol} / \mathrm{L})$ was presented based on the division of amplification products in the chip, the level of foxp3 mRNA expression was normalized to the level of $\beta$-actin mRNA expression and presented as a percentage [29].

Statistical data processing was performed using SPSS Statistics 17.0, software (SPSS, USA). Obtained experimental data are presented as the mean \pm standard deviation. The reliability of the differences between the groups was evaluated by Mann-Whitney U-test. Differences were considered statistically significant at $p<0.05$. Survival analysis was performed using Kaplan-Meier method.

\section{RESULTS AND DISCUSSION}

Confirmation of the acute GVHD induced by the injection of histoincompatible BM with lymph node cells is splenomegaly, which characteristic feature was an increase in the spleen index (Fig. 1). In the recipients of syngeneic BM (group 3), the spleen index was not significantly different from that of intact mice (group 1). When injecting histoincompatible BM (group 4), the spleen index increased by $30 \%$ compared to the rate of recipients of syngeneic BM (group 3), which indicates the development of GVHD.

One of the clinical signs that characterizes the severity of the GVHD is the survival rate of experimental animals. At the transplantation of histoincompatible BM, a statistically significant decrease in the number of animals that survived till the $16^{\text {th }}$ day of the experiment compared to the recipients of group 3 (Fig. 2) was established.

In evaluating the immunoregulatory effect of FNCs in animals with GVHD (groups 5 and 6, respectively), a decrease in the spleen index was established, and in the application of cryopreserved cells - to the level of group 3 (Fig. 1). The transplantation of FNCs contributed to the higher number of surviving animals during the observation period (Fig. 2). After administration of both native and cryopreserved FNCs (groups 5 and 6), this parameter was 1.4 and 1.6 times higher than in group 4.

The development of GVHD after the injection of histoincompatible BM is associated with the development of autoimmune disease, that is, with the presence of the autoreactive clone of T-effector cells, which are differentiated from donor hematopoietic stem cells in the recipients' body [2]. Experimental models of GVHD showed that donor effector T-cells attack various tissues of the recipient's body, including the thymus, destroying its architectonics, which leads to thymic involution and lymphopenia $[30,31]$. Moreover, this leads to a violation of the central positive and negative selection of potentially autoreactive effector T-cells [32]. At the same time, there is a decrease in the ability of the thymus of the recipient with GVHD to the production of cells with suppressor activity. In addition, Miura Yu et al. showed that Treg in the recipients with GVHD with aplasia of the hematopoietic system after irradiation is formed precisely from the donor bone marrow [30]. It is obvious that a correction of Treg immunity is required at the GVHD.

As shown above, the transplantation of syngeneic BM to recipients (group 3) did not cause the development of GVHD (see Fig. 1). In the spleen of animals in this group, there was no statistically significant decrease in the number of FOXP3 cells compared to group 1 (Fig. 3 ).

Chen $\mathrm{X}$. et al. showed the reduction of the number of $\mathrm{CD}^{+} \mathrm{FOXP3^{+ }}$ cells in the spleens of mice with acute GVHD, which was modelled similar to our method [33]. In a clinical trial, in patients with an increased severity of acute GVHD after allogeneic transplantation of hematopoietic stem cells, a decrease in the Treg CD4+CD25+FOXP3 ${ }^{+}$number in peripheral blood was confirmed [34]. This is consistent with the data we received on the decrease in the number of FOXP3+ cells in 3.8 times in animals with GVHD (group 4) compared with group 3. 


\begin{tabular}{|c|c|c|c|}
\hline GENE NAME AND NUMBER IN GENBANK & FORWARD (F) I REVERSE (R) PRIMERS & PRODUCT LENGTH & \\
\hline $\begin{array}{l}\text { foxp3, Mus musculus forkhead box P3 (Foxp3) } \\
\text { NM_054039.2 }\end{array}$ & $\begin{array}{l}\text { F:CCTCTCGGACCCGGCCCAAG } \\
\text { R:CCCAGTGATGGGAAGGAACA }\end{array}$ & 220 bp & $\begin{array}{l}\text { and housekeeping } \\
\text { gene - beta actin }\end{array}$ \\
\hline $\begin{array}{l}\beta \text {-actin, Mus musculus actin } \\
\text { NM_007393.3 }\end{array}$ & $\begin{array}{l}\text { F: CACTGCCGCATCCTCTTCCT } \\
\text { R: AGGAAGGCTGGAAAAGAGCC }\end{array}$ & 113 bp & \\
\hline
\end{tabular}

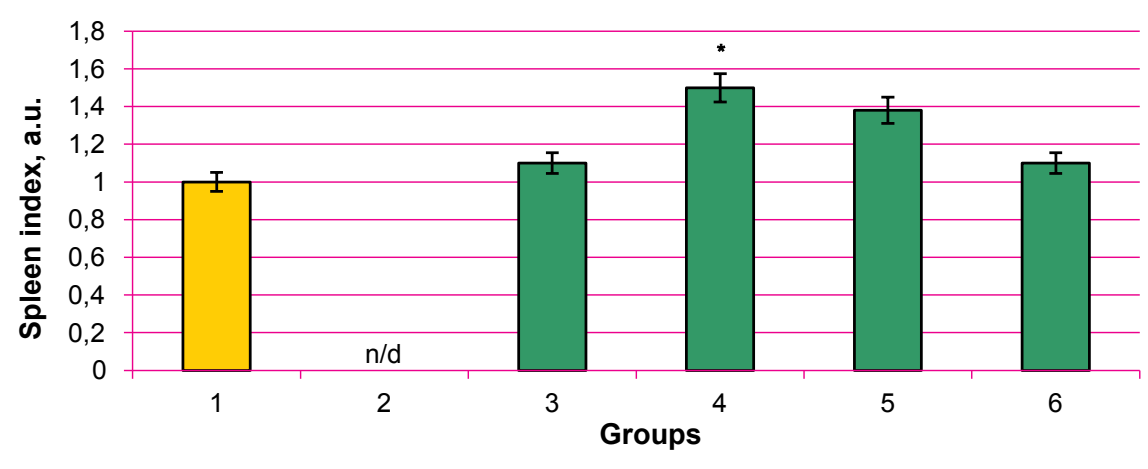

The transplantation of native or cryopreserved FNCs (group 5 and 6) in animals with GVHD caused an increase in Treg number compared to animals with this pathology development (group 4) (Fig. 3). At the same time, the stimulating effect of cryopreserved FNCs (group 6) on FOXP3 ${ }^{+}$ cells was 1.34 times as much as the effect after the injection of native FNCs (group 5). This indicates a greater ability of the cryopreserved fetal cells to exhibit an immunoregulatory effect on Treg, as evidenced by the survival of animals up to 16 days in group 6 (Fig. 2).

The ability of cryopreservation to act as a factor regulating the cell functions has been identified in our previous studies. It was found that after certain cryopreservation regimes in the fetal liver cells of the $18^{\text {th }}$ day of gestation, there was a significant increase in the expression of the ido gene compared with native cells of this gestation period, which gave them more pronounced immunoregulatory properties [35]. The enhancement of the therapeutic potential of fetal liver cells after cryopreservation was confirmed at the local GVHD development, where the injection of these cells resulted in an increase in the expression of the tgf- $\beta$ gene in recipients' regional lymph nodes [36].

Meijerink M. et al. found that cryopreserved monocytes and immature dendritic cells have an abnormal ability to produce cytokines. In particular, after cryopreservation of immature dendritic cells, the ability to produce anti-inflammatory cytokine IL-10 increased 3.6 times [37].

A similar effect of low-temperature preservation factors, namely, the stimulation of ido gene expression and the production of anti-inflammatory mediators transforming growth factor $\beta$ and IL-10, was also detected on FNCs $[16,38]$. The use of the specific cryopreservation regime contributed to the redistribution of FNCs subpopulation into the glial cells, which, under the impact of one of the most powerful inflammatory mediators, IFN- $\gamma$, could increase the gene expression and the production of IDO [16]. The effect of this enzyme may enhance expression of FOXP3 transcription factor in naive CD4+ cells and differentiation of Treg [21]. Since in FNCs of the 12th day of gestation, which are transplanted for the treatment of GVHD, in addition to the micro- and macroglia as a potential IDO producers, there are also dendritic cells [39], whose participation in the differentiation of FOXP3 ${ }^{+}$Treg in the recipient is not excluded.

Treg activity is under the close supervision of foxp3 gene responsible for the synthesis of the FOXP3 transcription factor. Linked to DNA promoter, FOXP3 acts as a transcription repressor, as an antagonist of another transcription factor - the nuclear factor of activated T-lymphocytes (NFAT). Under the impact of FOXP3, the transformation of the CD4+ cells into an active Treg occurs by suppressing the transcription of the proinflammatory cytokines that are regulated by NFAT [40]. \ig. 1. Spleen index of experimental animals. Note: group 1 - intact mice $(C B A / H \times C 57 B I) F_{1}$; group 2 - irradiated mice $(C B A / H \times C 57 B I) F_{1}$, (no data - n/d); group 3 - irradiated mice $(C B A / H \times C 57 B I) F_{1}$, which were injected with syngeneic BM; group 4 - irradiated mice $(C B A / H \times C 57 B I) F_{1}$, which were injected with histoincompatible $C B A / H$ bone marrow; group 5 - irradiated mice $(C B A / H x C 57 B I) F_{1}$, which were injected with histoincompatible $B M$ and native FNCS; group 6 - irradiated mice (CBAVHXC57BI) $F_{1}$, which were injected with histoincompatible $B M$ and cryopreserved FNCs; $(n=10)$. * - the differences are statistically significant compared to the group $3, p<0.05$.

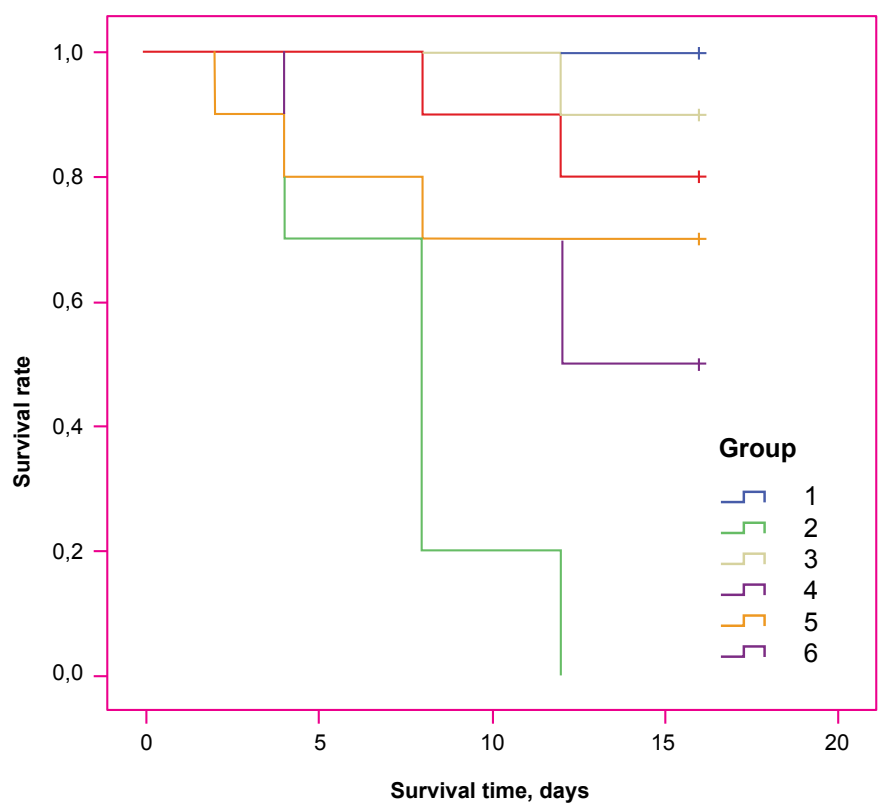

A Fig. 2. Survival rate of animals until the $16^{\text {th }}$ day, per group. Note: group 1 - intact mice (CBA/HXC57BI)F1; group 2 - irradiated mice $(C B A / H \times C 57 B I) F_{1}$, (no data - n/d); group 3 - irradiated mice $(C B A / H \times C 57 B I) F_{1}$, which were injected with syngeneic $B M$; group 4 - irradiated mice $(C B A / H x C 57 B I) F_{1}$, which were injected with histoincompatible CBA/H bone marrow; group 5 - irradiated mice (CBA) $H \times C 57 B I) F_{1}$, which were injected with histoincompatible $B M$ and native FNCs; group 6 - irradiated mice $(C B A / H \times C 57 B I) F_{1}$, which were injected with histoincompatible BM and cryopreserved FNCs; $n=10$.

The generation of FOXP3 ${ }^{+}$Treg occurs on the periphery and can be controlled by dendritic cells using several mechanisms, including the ID0-dependent pathway [41]. In particular, produced by IDO kynurenine binds to the aryl-hydrocarbon receptor (AhR) (Fig. 4), which is a cytosolic 

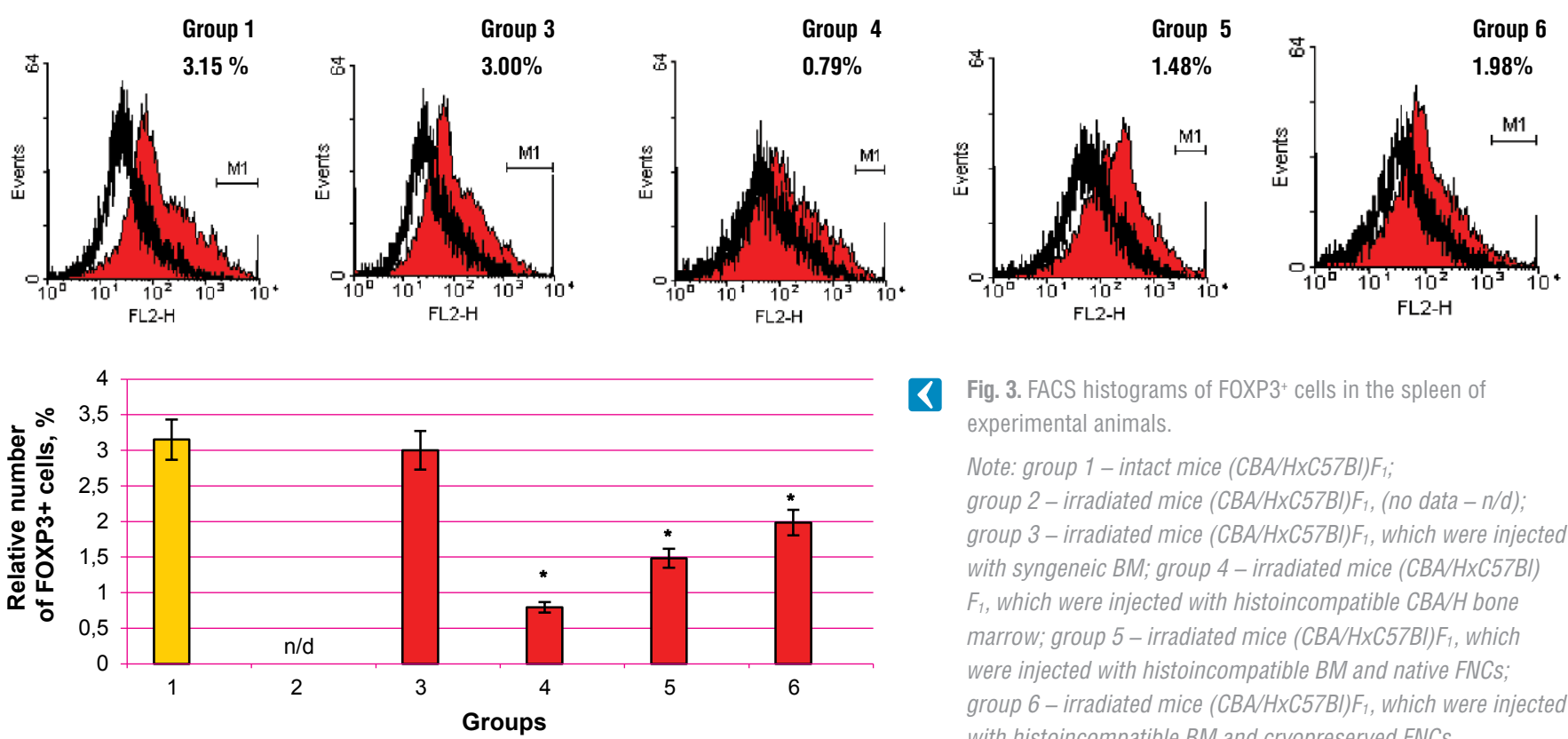

Fig. 3. FACS histograms of $\mathrm{FOXP3}^{+}$cells in the spleen of experimental animals

Note: group 1 - intact mice $(C B A / H \times C 57 B I) F_{1}$,

group 2 - irradiated mice $(C B A / H \times C 57 B I) F_{1}$, (no data $\left.-n / d\right)$; group 3 - irradiated mice $(C B A / H x C 57 B I) F_{1}$, which were injected with syngeneic BM; group 4 - irradiated mice (CBA/HxC57BI) $F_{1}$, which were injected with histoincompatible $C B A / H$ bone marrow; group 5 - irradiated mice $(C B A / H \times C 57 B I) F_{1}$, which were injected with histoincompatible BM and native FNCs; group 6 - irradiated mice $(C B A / H \times C 57 B I) F_{1}$, which were injected with histoincompatible BM and cryopreserved FNCS.

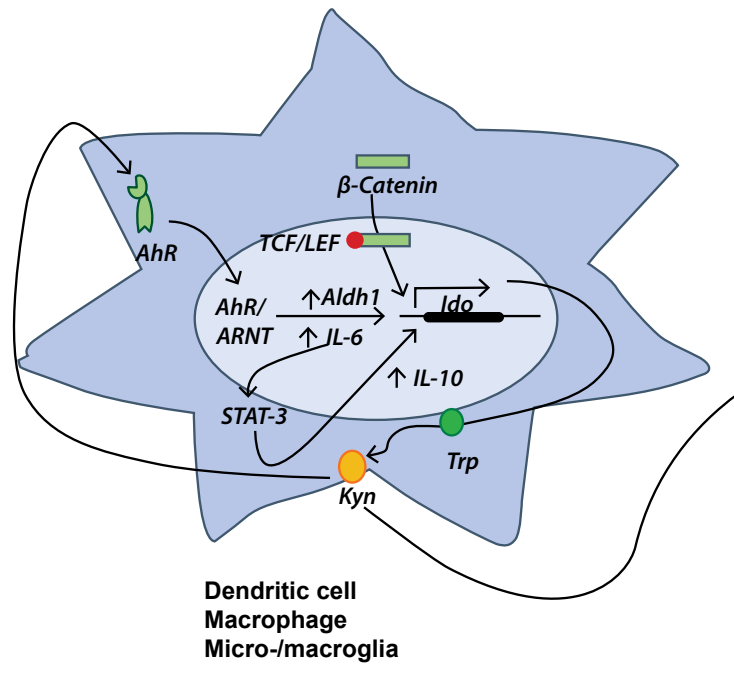

transcription factor and is usually found in the cytoplasm of T-cells in an inactive state, which is provided by its association with chaperone HSP90 [42]. The binding of kynurenine to AhR results in the dissociation of the AhR-HSP9O complex and transfer of AhR to kynurenine into the nucleus, followed by dimerization with aryl hydrocarbon receptor nuclear translocator (ARNT). This complex kynurenine-AhR-ARNT due to conformational rearrangements binds to the promoter region of a number of genes, namely: DNA methyltransferase (DNMT), which demethylated Foxp3 promoter, allowing the synthesis of Foxp3 protein; a gene that regulated the production of IL-10; as well as genes that ensure the production of the AhR, provide its self-regulation. There are all prerequisites to assume that, in such a way, other ID0-producing cells, namely macrophages, micro- and macroglia, can realize these functions as part of the heterogeneous population in the fetal brain (Fig. 4).

The level of foxp3 gene expression in the CD4+fraction of the splenocytes in animals with GVHD before and after transplantation of FNCs was evaluated. It was found that the level of foxp3 gene expression during the development of GVHD (group 4) was significantly lower than that of groups 1 and 3 (Fig. 5). This is confirmed by the well-known postulate that this disease develops at a decrease in the foxp3 gene expression, namely in Treg cells (group 4), resulting in a severe form of the immune conflict, which causes the maximum death of animals in this group the IDO-dependent pathway Note: cited by Cannon M. J. (edited by authors)

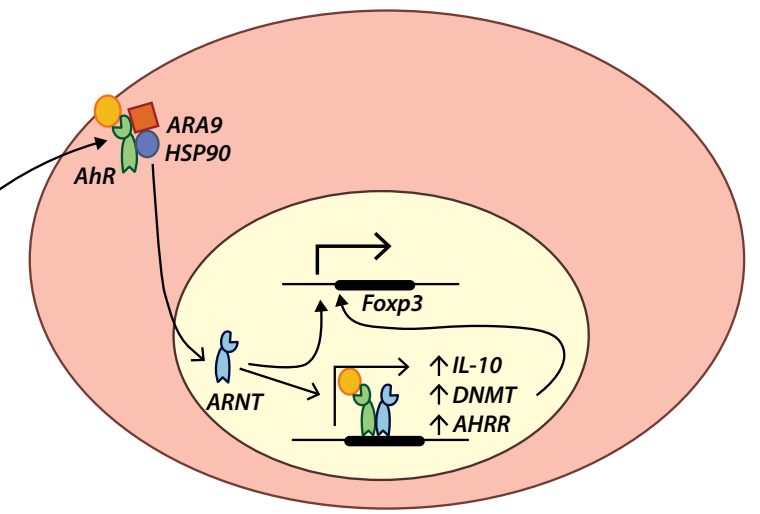

T-cell

(Fig. 2). The obtained results are consistent with the data of Miura Yu. et al. on the negative correlation of the level of foxp3 gene expression in peripheral blood mononuclears with the severity of the GVHD in humans [30].

After administration of native or cryopreserved FNCs to recipients with GVHD (groups 5 and 6 ), in the CD4+cells of the spleen, there was the increase of not only the FOXP3+ cells number (Fig. 2), but also the level of foxp3 gene expression in them (Fig. 5). Cryopreserved FNCs (group 6) had a higher immunomodulatory activity than these parameters in animals with GVHD (group 4). This was manifested as a larger parameter of the number of animals surviving for 16 days after the administration of FNCs, whereby cryopreserved FNCs (group 6) had in this case an advantage over the use of native cells (group 5) (Fig. 2).

The obtained results contradict the data of Moll G. et al. concerning the reduction of immune modulating and regulatory properties of bone marrow MSCs immediately after thawing, which leads to their reduced response to pro-inflammatory stimuli, and the abnormality of anti-inflammatory mediator production compared to native cells [43]. The authors associate this with activation of congenital immune attack, under the 


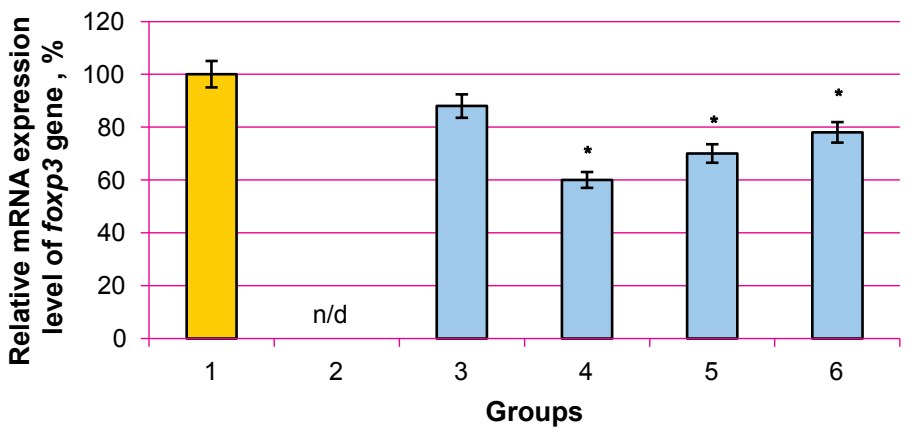

impact of cryopreserved MSCs; that is called an instant blood-mediated inflammatory reaction, which is implemented in the vessels and whose purpose is prevention the engraftment and activity of cells after their systemic administration. This may be the reason for the decrease in immunomodulatory properties of cryopreserved MSCs.

However, in our work, we used cryopreserved FNCs, which, after thawing, had been pre-cultured in vitro with IFN- $\gamma$, which allowed them to
Fig. 5. Relative mRNA expression level of foxp3 gene in $\mathrm{CD} 4^{+}$fraction of splenocytes of the experimental animals.

Note: group 1 - intact mice (CBA/HxC57BI)F Fi; group 2 - irradiated mice $(C B A / H \times C 57 B I) F_{1}$, (data were not determined $\left.-n / d\right)$; group 3 - irradiated mice $(C B A / H \times C 57 B I) F_{1}$, which were injected with syngeneic $B M$; group 4 - irradiated mice $(C B A / H x C 57 B I) F_{1}$, which were injected with histoincompatible CBA/H bone marrow; group 5 - irradiated mice $(C B A / H \times C 57 B I) F_{1}$, which were injected with histoincompatible BM and native FNCs; group 6 - irradiated mice (CBA/HXC57BI) $F_{1}$, which were injected with histoincompatible BM and cryopreserved FNCs; $n=10$. ${ }^{*}$ - the differences are statistically significant compared to the group 3 , $p<0.05$.

restore their functional potential for the production of ido gene [16] and allowed to realize immunosuppressive properties in vivo.

Thus, the conducted studies allow to broaden the understanding of the pathogenesis of GVHD development and to determine the mechanisms of immunoregulatory effects of native and cryopreserved fetal neural cells.

\section{CONCLUSION}

1. It has been established that acute GVHD in mice develops at decrease of Treg cell number and the level of foxp3 gene expression in the splenocytes.

2. The transplantation of native or cryopreserved murine FNCs to animals with GVHD resulted in an increase in the Treg number and expression level of foxp3 gene.

3. It has been shown that cryopreserved murine FNCs are more than native capable to the immunoregulation in animals with GVHD by affecting the Treg immunity, which contributed to a higher survival rate of recipients.

The study was carried out on the project № 2.2.6.78 «Study of the molecular mechanisms of regulation of bone marrow immunoreactivity by fetal cells» within the framework of the National Academy of Sciences of Ukraine program «Fundamental research on the most important problems of natural sciences».

\section{REFERENCES}

1. MacDonald KP, Hill GR, Blazar BR. Chronic graft-versus-host disease: biological insights from preclinical and clinical studies. Blood. 2017; 129(1):13-21. DOl:10.1182/blood-2016-06-686618.

2. Ghimire S, Weber D, Mavin E, et al. Pathophysiology of GVHD and other HSCT-Related Major Complications. Front Immunol. 2017; 8:79. DOl:10.3389/ fimmu.2017.00079

3. Antin JH. T-cell depletion in GVHD: less is more? Blood. 2011; 117(23):6061-6072. D0l:10.1182/blood-2011-04-348409.

4. Michalek J, Collins RH, Durrani HP, et al. Definitive separation of graft-versus-leukemia- and graft-versus-host-specific CD4+ $\mathrm{T}$ cells by virtue of their receptor beta loci sequences. Proc Natl Acad Sci U S A. 2003; 100(3):1180-1184.

5. Chang YJ, Zhao XY, Huang XJ. Strategies for Enhancing and Preserving Anti-leukemia Effects Without Aggravating Graft-Versus-Host Disease. Front Immunol. 2018; 9:3041. DOl:10.3389/fimmu.2018.03041.

6. Goltsev AN, Matsevitaya IYu, Lutsenko YeD, et al. On the Modification of Immunoreactivity of Myelotransplant after Cryopreservation. Probl Cryobiol Cryomed. 2010; 20(2):145-152.

7. Goltsev AN, Babenko NN, Dubrava TG, et al. Modification of the state of bone marrow hemopoietic cells after cryopreservation. Int J Refriger. 2006; 29(3):358-367.

8. Le Blanc K, Davies LC. Mesenchymal stromal cells and the innate immune response. Immunol Lett. 2015; 168(2):140-146. D0l:10.1016/j.imlet.2015.05.004.

9. Dunavin N, Dias A, Li M, McGuirk J. Mesenchymal Stromal Cells: What Is the Mechanism in Acute Graft-Versus-Host Disease? Biomedicines. $2017 ; \mathbf{5}(3): 39$. DOl:10.3390/biomedicines5030039.

10. Saad AG, Alyea EP, Wen PY, et al. Graft-versus-host disease of the CNS after allogeneic bone marrow transplantation. J Clin Oncol. 2009; 27(30): 147-9. DOl:10.1200/JC0.2009.21.7919.

11. Schroeder MA, DiPersio JF. Mouse models of graft-versus-host disease: advances and limitations. Disease Models \& Mechanisms. 2011; 4:318-333. D0l:10.1242/ dmm.006668.

12. Kamble RT, Chang CC, Sanchez S, Carrum G. Central nervous system graft-versus-host disease: report of two cases and literature review. Bone Marrow Transplant. 2007; 39(1):49-52.

13. Xiao J, Yang R, Biswas $S$, et al. Neural stem cell-based regenerative approaches for the treatment of multiple sclerosis. Mol Neurobiol. 2018; 55(4):3152-3171. DOl:10.1007/s12035-017-0566-7. 
14. Weston NM, Sun D. The potential of stem cells in treatment of traumatic brain injury. Curr Neurol Neurosci Rep. 2018; 18(1):1. D0l:10.1007/s11910-018-0812-z.

15. Pluchino $S$, Zanotti L, Brambilla $E$, et al. Immune regulatory neural stem/precursor cells protect from central nervous system autoimmunity by restraining dendritic cell function. PLoS One. 2009; 4(6):5959. DOl:10.1371/journal.pone.0005959.

16. Goltsev AN, Babenko NN, Dubrava TG, et al. Cryopreservation can regulate immunomodulatory properties of fetal neural cells. Cryobiology. 2018; 85:168.

17. Le Floc'h N, Otten W, Merlot E. Tryptophan metabolism, from nutrition to potential therapeutic applications. Amino Acids. 2011; 41:1195-1205.

18. Munn DH, Sharma MD, Baban B, et al. GCN2 kinase in T cells mediates proliferative arrest and anergy induction in response to indoleamine 2,3-dioxygenase. Immunity. 2005; 22(5):633-642.

19. Munn DH, Mellor AL. Indoleamine 2,3 dioxygenase and metabolic control of immune responses. Trends Immunol. 2013; 34(3):137-143. D0l:10.1016/j. it.2012.10.001.

20. Metz $R$, Rust $S$, Duhadaway JB, et al. IDO inhibits a tryptophan sufficiency signal that stimulates mTOR: A novel ID0 effector pathway targeted by D-1-methyltryptophan. Oncolmmunology. 2012; 1:1460-1468.

21. Wu H, Gong J, Liu Y. Indoleamine 2, 3-dioxygenase regulation of immune response (Review). Mol Med Rep. 2018; 17(4):4867-4873.

22. Guillemin GJ, Smith DG, Smythe GA, et al. Expression of the kynurenine pathway enzymes in human microglia and macrophages. Adv Exp Med Biol. 2003; 527:105-112.

23. Guillemin GJ, Kerr SJ, Smythe GA, et al. Kynurenine pathway metabolism in human astrocytes: a paradox for neuronal protection. J Neurochem. 2001; 78:1-13.

24. Pemberton LA, Kerr SJ, Smythe G, Brew BJ. Quinolinic acid production by macrophages stimulated with IFN-gamma, TNF-alpha, and IFN-alpha. J Interferon Cytokine Res. 1997; 17:589-595

25. Guillemin GJ, Smythe G, Takikawa 0, Brew BJ. Expression of indoleamine 2,3-dioxygenase and production of quinolinic acid by human microglia, astrocytes, and neurons. Glia. 2005; 49(1):15-23.

26. Ukena SN, Grosse J, Mischak-Weissinger E, et al. Acute but not chronic graft-versus-host disease is associated with a reduction of circulating CD4(+)CD25(high) CD127(low/-) regulatory T cells. Ann Hematol. 2011; 90(2):213-218. D0l:10.1007/s00277-010-1068-0.

27. Goltsev AN, Dubrava TG, Gayevskaya YuA, et al. Foxp3 Gene Expression Value in Regulatory T Cells in Pathogenesis of Graft-Versus-Host Disease Induced with Cryopreserved Allogenic Material. Probl Cryobiol Cryomed. 2014; 24(4):322-331.

28. Shevelev AS. Reakcija «transplantat protiv hozjaina» i transplantacionnaja bolezn' [Graft-versus-host disease and transplant disease]. Moskva: Medicina Moscow: Medicine, 1976. 237 p. [In Russian]

29. Gottwald E, Muller O, Polten A. Semiquantitative reverse transcription - polymerase chain reaction with the Agilent 2100 Bioanalyzer. Electrophoresis. 2001; 22(16):4016-4022.

30. Miura Yu, Thoburn CJ, Bright EC, et al. Association of Foxp3 regulatory gene expression with graft-versus-host disease. Blood. 2004; 104(7):2187-2193.

31. Dudakov JA, Mertelsmann AM, O'Connor $M H$, et al. Loss of thymic innate lymphoid cells leads to impaired thymopoiesis in experimental graft-versus-host disease. Blood. 2017; 130(7):933-942.

32. Krenger W, Blazar BR, Holldnder GA. Thymic T-cell development in allogeneic stem cell transplantation. Blood. 2011; 117(25):6768-6776.

33. Chen $X$, Vodanovic-Jankovic $S$, Johnson B, et al. Absence of T-cell control of Th1 and Th17 cells is responsible for the autoimmune-mediated pathology in chronic graft-versus-host disease. Blood. 2007; 110:3804-3813.

34. Korsunsky IA, Rumyantsev $A G$, Bykovskaya $S N$. Rol' regulyatornykh T-kletok CD4+CD25+ i mezenkhimal'nykh stvolovykh kletok kostnogo mozga v podavlenii reaktsii transplantat protiv khozyaina [The role of regulatory $\mathrm{CD} 4^{+} \mathrm{CD} 25^{+} \mathrm{T}$ cells and bone marrow mesenchymal stem cells in suppressing graft versus host disease]. Onkogematologiya - Oncohematology. 2008; 3:45-51. [In Russian]

35. Goltsev AN, Dubrava TG, Lutsenko ED, et al. Uroven' ekspressii genov GATA-2 i IDO v kletkakh stvolovogo kompartmenta kriokonservirovannoy fetal'noy pecheni raznykh srokov gestatsii [Expression rate of GATA2 and IDO genes in cells of stem compartment of cryopreserved fetal liver of different gestation terms]. Tavricheskiy mediko-biologicheskiy vestnik - Scientific journal Tavricheskiy Mediko-Biologicheskiy Vestnik. 2012; 15(3):81-83. [In Russian]

36. Goltsev AN, Dubrava TG, Lutsenko ED, et al. Proyavlenie immunokorrigiruyushchego effekta kriokonservirovannykh kletok fetal'noy pecheni raznykh srokov gestatsii $\checkmark$ usloviyakh razvitiya eksperimental'noy modeli reaktsii «transplantat protiv khozyaina» [The manifestation of the immunocorrective effect of cryopreserved fetal liver cells of different gestational periods in condition of experimental model of graft versus host disease]. Geny i kletki - Genes \& Cells. 2010; 5(3):82-86. [In Russian]

37. Meijerink $M$, Ulluwishewa $D$, Anderson $R C$, et al. Cryopreservation of monocytes or differentiated immature DCs leads to an altered cytokine response to TLR agonists and microbial stimulation. J Immunol Methods. 2011; 373(1-2):136-142.

38. Goltsev AN, Porozhan leA, Babenco NN, et al. Cryopreservation of fetal neural cells causes change of their ido gene expression. Abstract book of Annual Scientific Conference of SLTB. 2014, 8-10 October, London, UK p. 66.

39. Prinz M, Priller J. Microglia and brain macrophages in the molecular age: from origin to neuropsychiatric disease. Nature reviews neuroscience. 2014; 15:300-312.

40. Torgerson T.R, Genin A, Chen C, et al. FOXP3 inhibits activation-induced NFAT2 expression in T cells thereby limiting effector cytokine expression. J Immunol. 2009; 183(2):907-915. DOl:10.4049/jimmunol.0800216.

41. Kushwah R, Hu J. Role of dendritic cells in the induction of regulatory T cells. Cell Biosci. 2011; 1(1):20. D0l:10.1186/2045-3701-1-20.

42. Cannon MJ, Ghosh D, Gujj S. Signaling Circuits and Regulation of Immune Suppression by Ovarian Tumor-Associated Macrophages. Vaccines (Basel). 2015; 3(2): 448-466.

43. Moll G, Alm JJ, Davies LC, et al. Do cryopreserved mesenchymal stromal cells display impaired immunomodulatory and therapeutic properties? Stem Cells. 2014; 32(9):2430-2442.

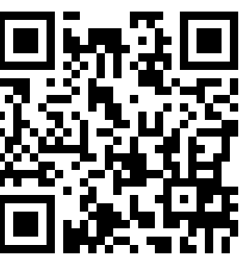

ARTICLE ON THE SITE

TRANSPLANTOLOGY.ORG
The authors indicate no potential conflicts of interest.

Received: February 20, 2019

Accepted: May 31, 2019 